\title{
Penerapan Konseling Adiksi Narkoba di Balai Rehabilitasi Badan Narkotika Nasional (BNN) Tanah Merah Samarinda
}

\author{
Rudy Hadi Kusuma \\ Institut Agama Islam Negeri (IAIN) Samarinda \\ rudi.hadi@iain-samarinda.ac.id
}

\begin{abstract}
In East Kalimantan, many people use Substance Use Disorders (GPZ) due to drug use that require counseling services in rehabilitation. Related research to study the qualifications and competencies of counselors involving drug counseling, techniques used, evaluation, coordination and solutions in the application of drug counseling at the National Narcotics Rehabilitation Agency (BNN) Tanah MerahSamarinda. This research uses descriptive qualitative method. Data sources consist of primary and secondary data sources. Collection techniques used are interviews, observation, and study documentation. Data analysis techniques consist of data reduction, data display, conclusion drawing. The technique of checking validity data uses credibility, transferability, dependability, and confirmability. The results showed that this study involved 13 people, 11 people from health education and 1 psychologist. Counseling techniques used consist of individual counseling, group counseling and family counseling as well as cognitive and behavioral therapy (CBT). Clients receive experience and knowledge to support healthy and proven life. The hard character of the client and the negative family stigma often become difficult in providing services. However, through the approval of individual humanists, patience and high service commitment can work well.
\end{abstract}

Keywords: Drug addiction, counseling, BNN Samarinda

\begin{abstract}
Abstrak
Di Kalimantan Timur banyak orang mengalami Gangguan Penggunaan Zat (GPZ) sebagai akibat dari penyalahgunaan narkoba yang membutuhkan layanan konseling adikasi dalam rehabilitasi. Penelitian bertujuan untuk mengetahui kualifikasi dan kompetensi konselor yang menerapkan konseling adiksi narkoba, teknik yang digunakan, dampak, kendala dan solusi dalam penerapan konseling adiksi narkoba di Balai Rehabilitasi Badan Narkotika Nasional (BNN) Tanah Merah-
\end{abstract}


Samarinda. Penelitian ini menggunakan metode kualitatif deskriptif. Sumber data terdiri dari sumber data primer dan sekunder. Teknik pengumpulan yang digunakan adalah wawancara, observasi, dan studi dokumentasi. Teknik analisis data terdiri dari data reduction, data display, conclusion drawing. Teknik pemeriksaan keabsahan data menggunakan credibility, transferability, dependability, dan confirmability. Hasil penelitian menunjukkan bahwa tenaga konselor berjumlah 13 orang, 11 orang dari pendidikan kesehatan dan 1 orang psikolog. Teknik konseling yang digunakan terdiri dari konseling individual, konseling kelompok dan konseling keluarga serta terapi kognitif dan behavior (CBT). Klien memperoleh pengalaman dan bekal pengetahuan untuk menjalani hidup sehat dan bermakna. Karakter keras dari klien dan stigma negatif keluarga klien sering kali menjadi hambatan dalam memberikan layanan. Namun, melalui pendekatan individual yang humanis, penuh kesabaran dan komitmen tinggi layanan konseling dapat berjalan dengan baik.

Kata Kunci: Adiksi narkoba, konseling, BNN Samarinda

\section{Pendahuluan}

Narkoba merupakan istilah yang sudah tidak asing bagi siapapun. Narkoba adalah singkatan dari narkotika dan obat atau bahan berbahaya. Selain "narkoba", istilah lain yang diperkenalkan khususnya oleh Kemenkes RI adalah Napza yang merupakan singkatan dari narkotika, psikotropika, dan zat adiktif. Napza merupakan kelompok senyawa yang umumnya memiliki resiko menimbulkan efek kecanduan bagi penggunanya. Menurut pakar kesehatan, Napza adalah senyawa-senyawa yang biasa dipakai untuk membius klien saat hendak dioperasi atau obat-obatan untuk penyakit tertentu. Secara khusus narkotika sendiri adalah obat-obatan yang dapat meningkatkan relaksasi dan mengurangi rasa sakit serta kecemasan pada penggunanya.

Narkoba sebenarnya sangatlah berguna dan bermanfaat apabila digunakan sesuai dengan kepentingan pelayanan kesehatan atau medis maupun untuk pengembangan ilmu pengetahuan atau kegiatan penelitian yang bersifat ilmiah. Namun, kini persepsi itu disalahartikan akibat pemakaian dengan dosis dan tujuan yang tidak semestinya. Faktanya, yang terjadi selama ini narkoba justru banyak disalahgunakan pemanfaatannya. Hal tersebut telah mengakibatkan dampak buruk yang sangat berbahaya dan berkepanjangan serta merugikan banyak pihak.

1 Feldman, "Understanding Psychology" Terj. Petty Gina Gayatri dan Putri Nurdina Sofyan, Pengantar Psikologi, Edisi Kesepuluh, (Jakarta: Salemba Humanika, 2012), hal. 205. 
Narkoba bisa menimbulkan efek ketergantungan atau kecanduan bagi penggunanya. Oleh karena itu, pengguna bisa menjadi "pecandu narkoba" atau disebut pula "orang dengan gangguan penggunaan zat (GPZ) narkoba" untuk istilah yang digunakan pihak Badan Narkotika Nasional (BNN) saat ini. Orang dengan gangguan penggunaan zat (GPZ) narkoba adalah korban dari ketidakpedulian masyarakat yang memilih diam ketika menemukan penyakit masyarakat tersebut. Padahal, jika cepat dilaporkan untuk direhabilitasi maka jumlah orang dengan gangguan penggunaan zat (GPZ) narkoba bisa ditekan. Hal ini begitu penting karena merupakan langkah nyata yang sudah difasilitasi Negara dalam rangka menangani permasalahan orang dengan gangguan penggunaan zat (GPZ) narkoba di Indonesia, sebagaimana diamanatkan Undang-Undang Nomor 35 Tahun 2009 tentang Narkotika dan dijabarkan kembali dalam Pasal 54 yang berbunyi "Pecandu Narkotika dan korban penyalahgunaan Narkotika wajib menjalani rehabilitasi medis dan rehabilitasi sosial". Hal tersebut diperkuat pula dengan peraturan bersama antara Ketua Mahkamah Agung RI Nomor: 01/PB/MA/III/2014, Menteri Hukum dan Hak Asasi Manusia RI Nomor: 03 Tahun 2014, Menteri Kesehatan RI Nomor: 11 Tahun 2014, Menteri Sosial RI Nomor: 03 Tahun 2014, Jaksa Agung RI Nomor: PER-005/A/JA/03/2014, Kepala Kepolisian Negara Republik Indonesia Nomor: 1 Tahun 2014 dan Kepala Badan Narkotika Nasional Republik Indonesia Nomor: PERBER/01/III/2014/BNN tentang penanganan pecandu narkotika dan korban penyalahgunaan narkotika ke dalam lembaga rehabilitasi.

Budaya merehabilitasi dinilai menjadi pilihan yang lebih baik dibandingkan pemidanaan penjara terhadap pengguna narkoba dalam rangka mengatasi persoalan narkoba. Oleh karena itu telah banyak dibangun Balai Rehabilitasi untuk menangani orang dengan gangguan penggunaan zat (GPZ) narkoba di wilayah Indonesia. Termasuk salah satunya telah dibangun sebuah Balai Rehabilitasi Badan Narkotika Nasional (BNN) di Jl. Ruas Samarinda Bontang KM. 6, Tanah Merah, Kota Samarinda. Mengingat Samarinda juga menempati posisi sebagai wilayah yang banyak terdapat kasus penyalahgunaan narkoba. Balai rehabilitasi BNN Tanah Merah Samarinda sudah mulai beroperasi sejak bulan November tahun 2013. Sejak saat itu, sudah 80 orang yang direhabilitasi, 15 orang diantaranya sudah menyelesaikan program rehabilitasi medis dan sosial secara terintegrasi.

Terdapat beberapa orang konselor adiksi yang bekerja di Balai Rehabilitasi BNN Tanah Merah Samarinda. Mereka bertugas memberikan layanan konseling adiksi untuk penanganan orang dengan gangguan penggunaan zat (GPZ) narkoba. Konseling adiksi adalah layanan profesional yang diberikan oleh konselor adiksi kepada orang dengan gangguan penggunaan zat (GPZ) narkoba agar dapat menghadapi permasalahan yang disebabkan oleh penggunaan zat-zat beracun yang merusak tubuh serta menimbulkan ketergantungan. Pelayanan konseling profesional tentu hanya bisa dilaksanakan 
oleh konselor yang memiliki standar kualifikasi dan kompetensi yang memadai yang diperoleh melalui pendidikan ataupun pelatihan khusus atau on job training. Keefektifan atau dampak positif pelayanan terhadap konseli (orang dengan gangguan penggunaan zat (GPZ) narkoba) tergantung proses penerapan layanan konseling adiksi narkoba yang diberikan.

Terdapat beberapa hasil penelitian terdahulu yang relevan dengan penerapan konseling adiksi narkoba dalam rangka menangani orang dengan gangguan penggunaan zat (GPZ) narkoba. Pertama, penelitian Bagus Setiawan dan Mohamad Thohir (2015) yang berjudul Bimbingan dan Konseling Islam bagi Orang dengan gangguan penggunaan zat (GPZ) Narkoba di Pesantren Dzikrussyifa' Asma' Berjomusti Sendang Agung Paciran Lamongan. ${ }^{2}$ Hasil penelitian menunjukkan bahwa teknik konseling yang digunakan di tempat penelitian dalam rangka merehabilitasi orang dengan gangguan penggunaan zat (GPZ) narkoba adalah teknik directive counseling karena lebih banyak peran aktif pengasuh dalam proses rehabilitasi. Penelitian ini menunjukkan bahwa konseling direktif yang dilaksanakan ini termasuk teknik konseling yang cocok digunakan dalam penanganan orang dengan gangguan penggunaan zat (GPZ) narkoba.

Kedua, penelitian Aliah B. Purwakania Hasan dan Abas Mansur Tamam (2017) yang berjudul Konseling Adiksi Narkoba di Pesantren dengan Pendekatan Tarkiyatun Nafs Imam Al-Ghazali. ${ }^{3}$ Hasil penelitian ini menkonstruksi secara teoritis indikator kesehatan spiritual yang terdiri dari kokohnya aqidah, bebas penyakit hati, akhlak mulia berkembang, adab yang baik terbina dalam interaksi kehidupan, dan tercapainya kebahagiaan dunia serta akhirat. Konsep mujahadah dan riyadah merupakan hal penting yang merupakan prinsip modalitas dalam melaksanakan penanganan orang dengan gangguan penggunaan zat (GPZ) narkoba dengan berbasis tąkiyatun nafs dalam pemikiran ilmiah Al Ghazali. Hasil penelitian ini akhirnya merekomendasikan penerapan konseling adiksi narkoba dengan menggunakan pendekatan tąkiyatun nafs Imam Ghazali dalam menangani orang dengan gangguan penggunaan zat (GPZ) narkoba di panti/balai rehabilitasi yang diselenggarakan oleh masyarakat. Hasil penelitian ini menggambarkan bahwa konseling adiksi narkoba bagi orang dengan gangguan penggunaan zat (GPZ) narkoba di Balai Rehabilitasi bisa menggunakan suatu pendekatan berbasis ajaran Islam, namun tentu perlu penyesuaian dengan agama yang dianut serta kompetensi dari konselor adiksi yang bertugas di Balai Rehabilitasi serta klien yang ditangani.

2 Bagus Setiawan dan Mohamad Thohir, "Bimbingan dan Konseling Islam bagi Pecandu Narkoba di Pesantren Dzikrussyifa' Asma' Berjomusti Sendang Agung Paciran Lamongan”, dalam Jurnal Bimbingan Konseling Islam, Vol. 5, No. 02, 2015, Hal. 92-108.

${ }^{3}$ Aliah B. Purwakania Hasan dan Abas Mansur Tamam, "Konseling Adiksi Narkoba di Pesantren dengan Pendekatan Tazkiyatun Nafs Imam Al-Ghazali”, dalam Konseling Religi: Jurnal Bimbingan Konseling Islam, Vol. 8, No. 2, 2017, Hal. 293-314. 
Ketiga, penelitian Musdalifah (2015) yang berjudul Peran Balai Rehabilitasi Badan Narkotika Nasional (BNN) Tanah Merah dalam Merehabilitasi Pecandu Narkoba di Kota Samarinda. ${ }^{4}$ Hasil penelitian menunjukkan bahwa peran Balai Rehabilitasi BNN Tanah Merah dalam merehabilitasi orang dengan gangguan penggunaan zat (GPZ) narkoba di Samarinda sudah tergolong cukup baik. Peran yang dimaksud adalah yang berkaitan dengan proses pemulihan dan perbaikan kondisi fisik maupun mental dari setiap klien (orang dengan gangguan penggunaan zat (GPZ) narkoba) agar dapat kembali hidup bermasyarakat seperti sediakala. Tahap-tahap rehabilitasi yang dilakukan pada orang dengan gangguan penggunaan zat (GPZ) narkoba yaitu: pertama, tahap penerimaan awal berupa tes urine, wawancara, pemeriksaan fisik, terapi simptomatik, dan rencana terapi. Kedua, tahap terapi medis berupa detoksifikasi dan stabilisasi. Ketiga, tahap rehabilitasi sosial dasar berupa pelatihan sikap, tingkah laku, pola pikir, dan kepribadian melalui pembinaan jasmani dan rohani. Terakbir, tahap rehabilitasi sosial lanjutan berupa sosialisasi dengan masyarakat umum melalui program vokasional dan perbaikan pola hidup sehat. Semua tahap ini sudah dilakukan terlihat dari peran seluruh pengelola Balai Rehabilitasi BNN Tanah Merah Samarinda dalam menjalankan tugas dan fungsinya masing-masing. Hasil penelitian ini belum menunjukkan tentang kualifikasi dan kompetensi serta peran konselor adiksi yang bertugas di Balai Rehabilitasi dalam menerapkan konseling adiksi narkoba guna membantu penanganan klien serta tentang teknik konseling yang digunakan, sehingga masih perlu diteliti lebih lanjut.

Keempat, penelitian Dini Farhana Baharudin, dkk (2013) yang berjudul Family intervention for the treatment and rebabilitation of drug addiction: an exploratory study (Intervensi Keluarga untuk Perawatan dan Rehabilitasi Kecanduan Narkoba: Sebuah Studi Eksplorasi). ${ }^{5}$ Tujuan penelitian ini untuk mengeksplorasi pengalaman keluarga yang menjalani program intervensi keluarga di agen perawatan dan rehabilitasi narkoba yang terletak di kota Kuala Lumpur, Malaysia. Secara khusus, keluarga diminta untuk mengomentari pengalaman mereka menghadiri program dan seberapa banyak peningkatan mereka disebabkan oleh program dan faktor-faktor lain. Hasil penelitian ini yaitu ditemukan bahwa lima tema muncul dari analisis, yakni: aliansi terapeutik antara konselor dan peserta; hal-hal bermanfaat yang diterima peserta dari program; hal-hal yang bermanfaat bagi peserta mereka lakukan sendiri selama mereka terlibat dalam perawatan; hal-hal yang bermanfaat bagi peserta yang dipelajari dalam program yang terus mereka gunakan; dan elemen tidak membantu dalam

${ }^{4}$ Musdalifah, "Peran Balai Rehabilitasi Badan Narkotika Nasional (BNN) Tanah Merah dalam Merehabilitasi Pecandu Narkoba di Kota Samarinda", dalam eJournal Ilmu Pemerintaban, Vol. 3, No. 2, 2015, Hal. 718-730.

5 Dini Farhana Baharudin, et al., "Family Intervention for the Treatment and Rehabilitation of Drug Addiction: an Exploratory Study", Journal of Substance Use, ISSN: 14659891, DOI: 10.3109/14659891.2013.799239, 2013, page. 1-6. 
program. Temuan mendukung asumsi bahwa program intervensi keluarga memiliki potensi positif untuk mendukung anggota keluarga dalam perawatan dan rehabilitasi kecanduan narkoba. Hasil penelitian ini lebih menekankan pada intervensi keluarga, namun merupakan bagian yang tidak dapat dipisahkan dari konseling keluarga yang merupakan bagian dari konseling adiksi. Namun berkaitan dengan pelibatan keluarga di Balai Rehabilitasi Tanah Merah Samarinda belum digali sehingga masih perlu digali lebih dalam dengan menajdikan penelitian di atas sebagai penguatan.

Berdasarkan pemaparan di atas, peneliti melakukan penelitian tentang penerapan konseling adiksi narkoba di Balai Rehabilitasi BNN Tanah Merah Samarinda yang belum pernah diteliti sebelumnya. Adapun tujuan penelitian ini adalah untuk mengetahui kualifikasi dan kompetensi konselor yang menerapkan konseling adiksi narkoba, teknik dan tahapan proses penerapan konseling adiksi narkoba, dampak bagi klien, serta kendala dan solusi dalam penerapan konseling adiksi narkoba di Balai Rehabilitasi Badan Narkotika Nasional (BNN) Tanah Merah-Samarinda. Sehingga hasilnya diharapkan dapat memberikan sumbangsih positif bagi perbaikan penerapan konseling adiksi demi pemulihan klien di Balai Rehabilitasi.

Penelitian ini merupakan jenis penelitian field research (penelitian lapangan). Pendekatan yang digunakan dalam penelitian ini adalah pendekatan deskriptif kualitatif. Data dalam penelitian ini adalah data tentang penerapan konseling adiksi narkoba yang dilaksanakan di Balai Rehabilitasi BNN Tanah Merah Samarinda. Sedangkan sumber data terbagi menjadi sumber data primer dan sekunder. Sumber data primer dalam penelitian ini adalah 3 orang Konselor Adiksi, sedangkan sumber data sekunder adalah Kepala Balai Rehabilitasi, 3 orang klien rehabilitasi, dan berbagai dokumen milik Balai Rehabilitasi BNN yang berkaitan dengan penelitian ini serta ditambah pendapat ahli bimbingan dan konseling untuk memperkuat hasil penelitian ini. Teknik pengumpulan data terdiri dari wawancara, observasi, dan studi dokumentasi. Penelitian ini menggunakan teknik analisis data model Miles dan Huberman. Miles dan Huberman (1984), mengemukakan bahwa aktivitas dalam analisis data kualitatif dilakukan secara interaktif dan berlangsung terus menerus sampai tuntas dimulai dari data reduction, data display, conclusion drawing/verification. ${ }^{6}$ Pemeriksaan keabsahan data yang dilakukan yaitu seperti yang dikemukakan oleh Moleong, yakni menggunakan kriteria derajat kepercayaan (credibility), keteralihan (transferability), kebergantungan (dependability), dan kepastian (confirmability).

\footnotetext{
${ }^{6}$ Sugiyono, Metode Penelitian Kuantitatif, Kualitatif dan R\&D, (Bandung: Alfabeta, 2018), hal. 247.

${ }^{7}$ Lexy J. Moleong, Metode Penelitian Kualitatif, (Bandung : Remaja Rosdakarya, 2009),
} Hal. 324. 
Rudy Hadi Kusuma: Penerapan Konseling ... | 7

\section{Hasil dan Pembahasan}

Berdasarkan temuan penelitian yang diperoleh dari wawancara, observasi dan dokumentasi, maka berikut dibahas hasil penelitian untuk memperjelas mengenai penerapan konseling adiksi narkoba di Balai Rehabilitasi BNN Tanah Merah Samarinda dengan penjabaran empat rumusan masalah sebagai berikut: Kualifikasi dan Kompetensi Konselor Adiksi Narkoba di Balai Rehabilitasi BNN Tanah Merah Samarinda

Hasil penelitian yang telah diperoleh dari penggalian data atau informasi di Balai Rehabilitasi (Bareta) BNN Tanah Merah Samarinda berdasarkan hasil wawancara kepada konselor dan kepala Bareta serta dokumentasi dari dokumen terkait diketahui bahwa kualifikasi akademik konselor adiksi yang bekerja di Balai Rehabilitasi (Bareta) BNN Tanah Merah Samarinda adalah lulusan S1 atau tingkat Sarjana. Adapun hasil penelitian ini menunjukkan bahwa 13 orang konselor adiksi memiliki latar belakang pendidikan berbeda, diantaranya D-3 Keperawatan, D-3 Kesehatan Lingkungan, D-3 Kebidanan dan D-4 Kebidanan Pendidik, dan S-1 Psikologi. Sehingga belum ada yang merupakan lulusan bimbingan dan konseling.

Padahal menurut pakar bimbingan dan konseling bahwa konseling sebagai profesi bantuan mempunyai persyaratan pendidikan dan praktik secara khusus yang harus dipenuhi oleh pelaksananya yang disebut konselor. ${ }^{8}$ Sehingga disayangkan dari sekian banyaknya alumni S-1 bimbingan dan konseling (BK) dan Pendidikan Profesi Konselor (PPK) yang ada di Indonesia tidak ada yang menjadi konselor adiksi di Bareta Tanah Merah Samarinda. Padahal ketika sudah mengambil PPK selama setahun seseorang dapat memperoleh gelar profesi "Konselor" disingkat "Kons." Lulusan PPK berarti diakui sebagai konselor profesional yang wilayah kerjanya tidak lagi hanya seperti lulusan S-1 BK yang kebanyakannya berorientasi pada pendidikan sebagai guru BK namun lulusan PPK bisa ke masyarakat umum dengan bekerja di lembaga-lembaga pendidikan, industri, kesehatan, rehabilitasi, panti sosial ataupun membuka Biro Layanan Konseling secara mandiri dengan memiliki izin operasional dari organisasi profesi bernama Asosiasi Bimbingan dan Konseling Indonesia (ABKIN).

Mengenai wilayah kerja atau konteks tugas konselor pada Lampiran Permendikbud Nomor 27 tahun 2008 tentang Standar Kualifikasi Akademik dan Kompetensi Konselor di bagian Pendahuluan dijelaskan tentang konteks tugas konselor sebagai berikut:

"Konteks tugas konselor berada dalam kawasan pelayanan yang bertujuan mengembangkan potensi dan memandirikan konseli dalam pengambilan keputusan dan pilihan untuk mewujudkan kehidupan yang produktif, sejahtera, dan peduli kemaslahatan umum. Pelayanan yang

\footnotetext{
${ }^{8}$ Mungin Eddy Wibowo, Profesi Konseling Abad 21, (Semarang: Unnes Press, 2018), hal.
} 155. 
dimaksud adalah pelayanan bimbingan dan konseling, terutama dalam jalur pendidikan formal dan nonformal."

Bahkan sekarang sudah banyak pula lulusan Bimbingan dan Konseling Islam yang jurusannya berorientasi di luar pendidikan dalam arti lebih ke masyarakat luas dan mereka dinaungi organisasi profesi bernama PABKI (Perkumpulan Ahli Bimbingan dan Konseling Islam).

Walau demikian, semua konselor adiksi yang bekerja menangani klien di Bareta telah mendapat pelatihan khusus berkenaan dengan konseling adiksi narkoba. Terdapat pula lulusan SMA atau mantan klien Bareta yang melalui on job training diterima menjadi asisten konselor di Bareta. Proses memperoleh kualifikasi untuk mendapatkan posisi sebagai konselor yaitu proses mayor 1 tahun berupa masuk kantor di rumah damping dan proses residensial (mengikuti program yang dijalani klien) sekitar 2 minggu di Bareta. Selama proses pelatihan terdapat beberapa kompetensi yang ditanamkan pada calon konselor untuk menjadi bekal ketika mendapatkan posisi sebagai konselor di antaranya yaitu kompetensi konseling dasar, pemahaman program rehabilitasi, dan proses pendidikan berkaitan dengan konselor. Oleh karena itu, setidaknya mereka benar-benar sudah dibekali kompetensi yang cukup memadai untuk menjalankan konseling adiksi secara profesional. Hal tersebut dapat dilihat dari kinerja para konselor yang bekerja di Bareta sebagaimana diperoleh dari hasil penelitian bahwa data menunjukkan bahwa kinerja konselor adiksi yang selama ini bekerja di Bareta tergolong baik karena proses rekrutmen dan seleksi yang cukup ketat. Proses evaluasi kinerja pun terus dilakukan secara rutin setiap minggunya. Ada pula proses penerimaan penilaian kinerja dari pihak klien dan keluarga klien Bareta setiap 3 bulan sekali sebagai pengukuran tingkat kepuasan kinerja konselor yang menangani klien. Artinya evaluasi kinerja dilakukan sesuai standar yang berlaku yaitu menggunakan laporan kinerja sesuai standar ISO 971. Selain itu, klien dan keluarga klien diberikan kuesioner manual untuk mereka isi dalam rangka mengukur tingkat kepuasan kinerja konselor yang dilaksanakan setiap 3 bulan sekali.

Mengenai penerimaan konselor di Bareta yang sebenarnya juga merupakan pembukaan lowongan CPNS dari pusat yang menerima formasi konselor namun syarat akademik untuk dapat mengisi posisi itu bisa di luar lulusan S-1 BK/BKI dan PPK, sehingga tidak ada yang salah dengan para konselor yang direkrut di Bareta untuk menduduki posisi sebagai konselor adiksi. Pakar Bimbingan dan Konseling Prof. Dr. H. Mungin Eddy Wibowo, M.Pd., Kons. menuturkan bahwa payung hukum untuk konselor di luar lembaga pendidikan masih terbilang lemah, sehingga masih mudahnya seseorang menyebut dirinya atau disebut orang lain sebagai konselor, dalam arti

9 Permendiknas Nomor 27 Tahun 2008 tentang Standar Kualifikasi Akademik dan Kompetensi Konselor 
menduduki posisi sebagai konselor yang dapat menjalankan konseling. ${ }^{10}$ Padahal jika dilihat dari syarat kualifikasi akademik dan kompetensi konselor sebagaimana yang tercantum dalam Permendiknas No. 27 Tahun 2008 tentang Standar Kualifikasi Akademik dan Kompetensi Konselor, maka selain lulusan S$1 \mathrm{BK}$ dan PPK belum bisa bergelar Konselor.

Namun tidak ditutup kesempatan bagi yang memiliki keinginan dan ketulusan untuk mengabdikan diri menjadi praktisi BK untuk memberikan layanan konseling pada masyarakat yang membutuhkan apalagi wilayah Samarinda belum ada yang lulusan Pendidikan Profesi Konselor. Intinya penerimaan konselor walau tidak sesuai standar kualifikasi akademik yang disyaratkan karena lebih mengutamakan kebutuhan di masyarakat. Hal ini karena konseling merupakan pelayanan sosial atau kemasyarakatan karena klien atau konseli yang menerima layanan konseling anggota masyarakat dari berbagai kalangan yang berada dalam kondisi tertentu sehingga memerlukan pelayanan konseling. ${ }^{11}$ Termasuk kebutuhan masyarakat dari maraknya kasus penyalahgunaan narkoba, ini perlu disadari dan ditangani pula oleh konselor selain pihak terkait lainnya. Para konselor pun juga harusnya menyadari, bahwa dari kebanyakan kasus yang terjadi, ada pula penyalahgunaan narkoba yang sudah lazim terjadi di kalangan pelajar baik tingkat SMA bahkan sampai tingkat SD. ${ }^{12}$ artinya kasus penyalahgunaan narkoba harus ditanggapi serius karena sudah merusak generasi muda bangsa Indonesia.

\section{Teknik dan Tahapan Proses Penerapan Konseling Adiksi Narkoba di BNN Tanah Merah Samarinda}

Teknik konseling adiksi yang digunakan hampir sama seperti konseling konvensional. Teknik yang digunakan seperti konseling individual, konseling kelompok dan konseling keluarga, ditambah motivational interviewing, assessment, therapeutic community, serta terapi kognitif dan behavior (CBT).

Penerapan konseling individual tahapannya terdiri atas pengungkapan masalah (berkaitan dengan pemenuhan tugas MoD), interpretasi masalah dari konselor, leading (konselor berusaha memahamkan klien terhadap diri dan masalahnya), pemberian penguatan/motivasi dan advice dari konselor pada klien, restatement dari konselor, summary dan termination. Sedangkan konseling kelompok yang dilaksanakan di Balai Rehabilitasi BNN Tanah Merah Samarinda ada yang semacam peer group. Ada pula pembahasan materi umum dan kendala umum dari klien dalam menjalani program atau proses pemulihan.

10 Prof. Mungin Eddy Wibowo, Pakar Bimbingan dan Konseling/Guru Besar BK Universitas Negeri Semarang (Konsultan Ahli), Wawancara, Semarang, 30 Juli 2019

${ }^{11}$ Mungin Eddy Wibowo, Profesi Konseling Abad 21, (Semarang: Unnes Press, 2018), hal. 131.

12 Gibson \& Mitchell, "Introduction to Counseling and Guidance" Terj., Yudi Santoso, Bimbingan dan Konseling, Edisi Ketujuh, (Yogyakarta: Pustaka Pelajar, 2011), hal. 252. 
Sedangkan untuk pendekatan khusus atau secara keilmuan yang digunakan dalam konseling adiksi seperti pendekatan kognitif dan behavior, dan pendekatan yang disesuaikan dengan klien yang ditangani. Pelaksanaan konseling ini memang untuk pengentasan masalah klien, dalam pelaksanaannya secara ideal sudah terpenuhi, karena konseling memang dilaksanakan dalam berbagai pendekatan dan dari pendekatan itu dilaksanakan dengan teknik tertentu. Secara garis besar, pendekatan yang dilakukan oleh konselor adiksi sudah sesuai dengan pendekatan konseling pada umumnya hanya saja lebih disesuaikan dengan kondisi klien dan arah pemecahan masalahnya. Sebagaimana dijelaskan secara keilmuan bahwa pendekatan-pendekatan konseling dapat berorientasi pada ranah kejiwaan yaitu kognitif, yang mnekankan pada fungsifungsi kognisi (pikir), misalnya trait and factor theory. Afektif, menekankan pada fungsi-fungsi afeksi (rasa), misalnya client centered therapy. Psikomotorik, menekankan pada fungsi-fungsi psikomotor (gerak tingkah laku), seperti behavior therapy, rational emotive therapy (RET), transactional analysis, psichoanalysis, dan reality therapy. ${ }^{13}$

Konseling keluarga yang dilakukan dengan melibatkan pihak keluarga klien telah dijalankan dengan baik karena tanpa dukungan keluarga klien walaupun nantinya pulih akan ada kemungkinan bisa mengalami kekambuhan jika keluarga melakukan penolakan terhadap dirinya, masih ada stigma negatif terhadap dirinya, tidak care, tidak ada pengawasan, dan lainnya. Mengenai pentingnya intervensi keluarga telah dibuktikan dari hasil penelitian Baharudin yang menyebutkan bahwa program intervensi keluarga memiliki potensi positif untuk mendukung anggota keluarga dalam perawatan dan rehabilitasi kecanduan narkoba. ${ }^{14}$

Keseluruhan teknik, tahapan beserta pendekatan dalam ragam bentuk konseling adiksi yang diberikan pada klien hanya akan berhasil jika sesuai dengan karakteristik dan permasalahan klien, konselor hanya membantu klien lepas dari masalah kecanduannya dan menjadi pribadimyang lebih sehat dan baik lagi, namun yang menentukan tetap konseli. Sebagaimana pengrtian konseling sebagai upaya konselor untuk membantu konseli/klien dalam menunjukkan dan memberikan nasihat (advice) agar adanya perubahan terhadap permasalahan psikologis klien, akan tetapi yang harus melakukan perubahan tersebut adalah diri klien sendiri dengan usaha yang dilakukan secara sadar. ${ }^{15}$

13 Zainal Aqib, Ikbtisar Bimbingan dan Konseling di Sekolah, (Bandung: Yrama Widya, 2012), hal. 45.

14 Dini Farhana Baharudin, et al., "Family Intervention for the Treatment and Rehabilitation of Drug Addiction: an Exploratory Study", Journal of Substance Use, ISSN: 14659891, DOI: 10.3109/14659891.2013.799239, 2013, page. 1-6.

${ }^{15}$ Abdul Hayat, Bimbingan Konseling Qur'ani, (Yogyakarta: Pustaka Pesantren, 2017), hal. 75. 


\section{Dampak Penerapan Konseling Adiksi Narkoba bagi Klien di Balai Rehabilitasi BNN Tanah Merah Samarinda}

Dampak penerapan konseling adiksi narkoba bagi klien di Balai Rehabilitasi BNN Tanah Merah Samarinda terlihat dari perkembangan diri klien tercatat pada lembar case note/progress note (form terlampir) dengan bentuk evaluasi dari konselor, tim, dan MoD serta supervisor. Berdasarkan hasil penelitian ditemukan bahwa dampak penerapan konseling adiksi begitu positif bagi klien, bukan hanya membantu memulihkan dari kecanduan namun klien juga banyak memperoleh pengalaman dan bekal pengetahuan dalam menjalani hidup sehat dan bermakna di masa yang akan datang pasca selesai menjalani seluruh proses rehabilitasi alias pulih total dari kecanduannya. Sehingga klien siap untuk terjun kembali ke masyarakat sebagai orang normal.

Beberapa indikator dampak positif konseling adiksi yang klien rasakan di antaranya ialah pola pikir klien berubah jadi lebih baik, yang sebelumnya senang menyalahkan orang lain berubah menjadi berpikir yang lebih positif dan bisa lebih menghargai orang lain. Ada pula perubahan gaya hidup yang lebih sehat dan bersih. Cara komunikasi interpersonal menjadi lebih baik dan lebih sopan, juga meningkatnya kejujuran. Ingatan pun lebih baik karena efek penggunaan zat juga sudah berkurang. Ada pula yang pada akhirnya sudah tidak suka mencium baru asap rokok, sehingga mengonsumsi rokok terlebih narkoba pun sudah tidak tertarik. Klien juga lebih mampu mengenal dan menerima diri sendiri, tanggungjawab pada keluarga semakin disadari. Maka tujuan konseling telah tercapai sebagaimana dijelaskan bahwa tujuan konseling di antaranya adalah membantu individu dengan segala kemampuan yang dimiliki untuk mengatasi kesulitan dalam memahami dirinya sendiri dan mengatasi kesulitan dalam memahami lingkungannya termasuk lingkungan keluarga dan masyarakat. ${ }^{16}$

Dampak dari penerapan konseling adiksi yang telah diberikan pada klien di Balai Rehabilitasi, tergantung kolaborasi dalam tim ITP yang telah dibentuk yang terdiri dari konselor, psikolog, dokter, perawat dan pembina mental untuk membantu klien pulih dari kecanduan dengan penanganan medis dan sosial. Dampak ini harapannya jangka panjang karenanya berdasarkan penjelasan konselor adiksi Bareta bahwa klien selanjutnya akan mengikuti program pasca rehabilitasi di BNN Provinsi atau Kota.

Dampak penerapan konseling adiksi juga jadi ukuran efektivitasnya, sejauh ini sudah tergolong efektif walau tidak semua efektif sebagaimana penjelasan konselor adiksi Bareta, namun konseling adiksi memnag sudah teruji efektif untuk menangani klien pecandu narkoba sebagaimana penelitian terdahulu misalkan penelitian Bagus Setiawan dan Mohamad Thohir yang menunjukkan bahwa teknik konseling yang digunakan di tempat penelitian

${ }_{16}$ Zainal Aqib, Ikhtisar Bimbingan dan Konseling di Sekolah, (Bandung: Yrama Widya, 2012), hal. 45 . 
dalam rangka merehabilitasi orang dengan gangguan penggunaan zat (GPZ) narkoba yaitu teknik directive counseling dianggap tepat karena lebih banyak peran aktif pengasuh dalam proses rehabilitasi sehingga konseling ini diberikan pada kliennya. ${ }^{17}$

Kendala dan Solusi dalam Penerapan Konseling Adiksi Narkoba di Balai Rehabilitasi BNN Tanah Merah Samarinda

Penerapan konseling adiksi narkoba di Balai Rehabilitasi BNN Tanah Merah Samarinda tidak terlepas dari kendala. Di antara kendala tersebut ialah dari sisi klien yaitu blocking program dari klien karena merasa sudah pulih dan tidak perlu lagi menjalani program rehabilitasi, ada perbedaan perilaku dan katakata klien ke konselor dengan ke pihak lain, klien tidak terbuka atau tidak jujur. Ada pula klien sekedar menjalani hari demi hari, program demi program tanpa keseriusan atau kesungguhan untuk pulih termasuk ada yang selalu rindu untuk pulang ke rumah. Ada pula yang canggung saat perjumpaan awal dengan konselor.

Sedangkan kendala dari sisi konselor sendiri misalkan jika menghadapi masalah klien yang baru/belum pernah dihadapi, seperti gangguan psikologis/halusinasi. Jadi walaupun sudah didetoks, efek penggunaan secara psikologis masih ada pada diri klien. Sebagaimana yang dijelaskan oleh pihak American Counseling Association bahwa ketika bahan kimia ini dihilangkan (yang terjadi dalam proses perawatan dan pemulihan selanjutnya), defisit perkembangan masih tetap ada. ${ }^{18}$ Sehingga perlu ditangani secara pendekatan psikologis atau edukatif termasuk dengan proses konseling. Solusi untuk mengatasi kendala dari sisi konselor sendiri adalah dengan melakukan proses sharing atau koordinasi dengan tim ITP atau rekan sejawat. Solusi lain yang dilakukan konselor adalah terletak pada tahap awal menjalin menjalin rapport dengan klien dalam hubungan konseling, yakni pemberian penekanan tentang tugas, proses dan komitmen bersama demi keberhasilan konseling.

Sedangkan kendala dari sisi pihak keluarga klien di antaranya ada yang ingin menarik klien dari program, dengan alasan masalah stigma negatif keluarga terhadap pengguna narkoba/klien dan terhadap program rehabilitasi maupun karena alasan lainnya. Solusinya adalah dengan pendekatan yang lebih baik pada anggota keluarga klien untuk bersedia mendukung proses pemulihan klien dengan konseling atau penanganan lainnya. Keterlibatan keluarga sangat penting demi keberhasilan konseling bagi klien. Konselor sering menemukan anggota keluarga terlibat dalam konseling tidak harus untuk sendiri tetapi lebih untuk

17 Bagus Setiawan dan Mohamad Thohir, "Bimbingan dan Konseling Islam bagi Pecandu Narkoba di Pesantren Dzikrussyifa' Asma' Berjomusti Sendang Agung Paciran Lamongan”, dalam Jurnal Bimbingan Konseling Islam, Vol. 5, No. 02, 2015, Hal. 92-108.

${ }^{18}$ Ford Brooks \& Bill McHenry, A Contemporary Approach to Substance Use Disordes and Addiction Counseling, Second Edition, (Alexandria: American Counseling Association, 2015), Hal. 153. 
membantu mereka yang diidentifikasi sebagai pecandu alkohol atau pecandu. Pertama kontak dengan anggota keluarga biasanya berkaitan dengan metode dan cara intervensi pada orang yang kecanduan. ${ }^{19}$

\section{Penutup}

Kesimpulan dari hasil penelitian ini di antaranya ditemukan bahwa 13 orang konselor adiksi yang berkerja di Bareta Tanah Merah Samarinda memiliki latar belakang pendidikan berbeda, di antaranya D-3 Keperawatan, D-3 Kesehatan Lingkungan, D-3 Kebidanan dan D-4 Kebidanan Pendidik, dan S-1 Psikologi, sehingga belum ada yang merupakan lulusan bimbingan dan konseling. Walau demikian, semua konselor telah mendapat pelatihan khusus berkenaan dengan konseling adiksi narkoba. Teknik konseling yang digunakan sama seperti konseling konvensional yang terdiri dari konseling individual, konseling kelompok dan konseling keluarga, ditambah motivational interviewing, assessment, therapeutic community, serta terapi kognitif dan behavior (CBT). Tahapannya sesuai SOP konseling adiksi yang ditetapkan. Dampak penerapan konseling begitu positif bagi klien, bukan hanya pulih dari kecanduan namun juga banyak memperoleh pengalaman dan bekal pengetahuan dalam menjalani hidup sehat dan bermakna ke depannya. Kendala yang dihadapi dalam penerapan konseling cukup beragam tergantung pribadi klien dan keluarga klien yang dihadapi seperti penolakan menjalani program, karakter keras dari klien dan stigma negatif keluarga klien. Solusi yang dilakukan adalah pendekatan individual yang humanis, penuh kesabaran dan komitmen tinggi.

Hasil penelitian ini diharapkan dapat menjadi bahan panduan atau alternatif penyelesaian masalah dan bahan evaluasi diri bagi Konselor Adiksi maupun Calon Konselor Adiksi dalam menerapkan konseling adiksi narkoba bagi klien (orang dengan gangguan penggunaan zat (GPZ) narkoba) di Balai Rehabilitasi Badan Narkotika Nasional (BNN) manapun. Hasil penelitian ini juga dapat digunakan oleh Pengelola Balai Rehabilitasi BNN dalam mengevaluasi dan menindaklanjuti penerapan konseling adiksi narkoba di Balai Rehabilitasi yang dikelola guna meningkatkan keefektifan penerapan konseling adiksi dalam rangka membantu penyembuhan klien rehabilitasi, serta dapat digunakan pula oleh pengelola Balai Rehabilitasi BNN lainnya. Bagi pengelola juga diharapkan dapat merekrut lulusan bimbingan dan konseling khususnya yang telah mengambil pendidikan profesi konselor agar tenaga konselor adiksi di Balai Rehabilitasi lebih berkompeten sesuai bidang ilmu dan lebih profesional lagi. Seluruh rangkaian kegiatan atau proses penelitian sampai hasil yang diperoleh dapat menjadi acuan bagi peneliti lanjutan untuk melaksanakan penelitian yang serupa atau berupa pengembangan dari penelitian ini berkenaan dengan penerapan konseling adiksi narkoba.

${ }^{19}$ Ford Brooks \& Bill McHenry, A Contemporary ....., Hal. 153. 


\section{Bibliografi}

Aqib, Z. Ikbtisar Bimbingan dan Konseling di Sekolah. Bandung: Yrama Widya, 2012.

Baharudin, D.F., et al. (2013). Family Intervention for the Treatment and Rehabilitation of Drug Addiction: an Exploratory Study. Journal of Substance Use, ISSN: 1465-9891, 1-6. http://informahealthcare.com/jsu.

Brooks, Ford \& McHenry, B. A Contemporary Approach to Substance Use Disordes and Addiction Counseling (Second Edition). Alexandria: American Counseling Association, 2015.

Dariyo, A. Psikologi Perkembangan Remaja. Bogor Selatan: Ghalia Indonesia, 2012.

Feldman, R.S. Pengantar Psikologi: Terjemahan Understanding Psychology (Edisi Kesepulub). Terjemahan Petty Gina Gayatri dan Putri Nurdina Sofyan. Jakarta: Salemba Humanika, 2012.

Gibson, R.L. \& Mitchell, M.H. Bimbingan dan Konseling: Terjemahan Introduction to Counseling and Guidance (Edisi Ketujub). Terjemahan Yudi Santoso. Yogyakarta: Pustaka Pelajar, 2011.

Gladding, S.T. Konseling: Profesi yang Menyelurub (Edisi Keenam): Terjemahan Counseling: Comprehension of Profession. Terjemahan P.M. Winarno dan Lilian Yuwono. Jakarta: PT. Indeks, 2012.

Hasan, A.B.P. dan Tamam, A.M. (2017). Konseling Adiksi Narkoba di Pesantren dengan Pendekatan Tazkiyatun Nafs Imam Al-Ghazali. Konseling Religi: Jurnal Bimbingan Konseling Islam, 8 (2), 293-314.

Hayat, A. Bimbingan Konseling Qur'ani. Yogyakarta: Pustaka Pesantren, 2017.

Kementerian Kesehatan Republik Indonesia. Pedoman Konseling Gangguan Penggunaan Napza Bagi Petugas Kesehatan. 2010.

Moleong, L.J. Metode Penelitian Kualitatif. Bandung: Remaja Rosdakarya, 2016.

Musdalifah. (2015). Peran Balai Rehabilitasi Badan Narkotika Nasional (BNN) Tanah Merah dalam Merehabilitasi Pecandu Narkoba di Kota Samarinda. eJournal Ilmu Pemerintaban, 3 (2), 718-730. http://ejournal.ip.fisipunmul.ac.id/site.

Partodiharjo, S. Kenali Narkoba dan Musubi Penyalahgunaannya. Jakarta: Penerbit Erlangga, 2006.

Permendiknas Nomor 27 Tahun 2008 tentang Standar Kualifikasi Akademik dan Kompetensi Konselor.

Prayitno \& Amti, E. Dasar-dasar Bimbingan dan Konseling. Jakarta: Rineka Cipta, 2013. 
Setiawan, B. dan Thohir, M. (2015). Bimbingan dan Konseling Islam bagi Pecandu Narkoba di Pesantren Dzikrussyifa' Asma' Berjomusti Sendang Agung Paciran Lamongan. Jurnal Bimbingan Konseling Islam, 5 (2), 92-108.

Sugiyono. Metode Penelitian Kuantitatif, Kualitatif, dan R\&D. Bandung: Alfabeta, 2018.

Tawil, A.M., dkk. Penyalahgunaan Narkoba dan Penanggulangannya. Surabaya: BNP JATIM, 2010.

Undang-Undang Nomor 35 Tahun 2009 tentang Narkotika.

Wibowo, M.E. Profesi Konseling Abad 21. Semarang: Unnes Press, 2018.

Willis, S.S. Remaja dan Masalabnya. Bandung: Alfabeta, 2012. . Konseling Individual: Teori dan Praktek. Bandung: Alfabeta, 2014. 
16 Islamic Counseling: Jurnal Bimbingan dan Konseling Islam, Vol. 4, No. 1, 2020

Halaman sengaja dikosongkan 